$821: 398(497.11)$

https://doi.org/10.18485/kud_kp.2018.ch2

\author{
проф. др Александра Вранеш \\ проф. др Љиљана Марковић \\ Универзитет у Београду \\ Филолошки факултет
}

\title{
КРАТКЕ НАРОДНЕ ПРОЗНЕ ФОРМЕ (ПОСЛОВИЦЕ И ЗАГОНЕТКЕ) КАО БАШТИНИЦИ КУЛТУРНОГ И ЕТНИЧКОГ НАСЛЕЪА МИГРАНАТА И ДОМАЋИНА
}

\section{Сажетак}

Кратке прозне форме, нарочито народне пословице и загонетке, баштиници су културног и верског наслеђа једног народа. Оне носе собом веровања, обичаје, обреде, уврежена схватања, заблуде, предрасуде, уобичајене ставове о друштвеним појавама, међуљудским односима, природним релацијама и њиховом доживљавању. Они каткад о једном народу откривају више од обимних етнографских и историјских студија, а истовремено кроз игру и досетку могу да буду облик едукације, културног приближавања и елементарног овладавања лингвистичким вештинама, значајним како за мигранте, тако и за домаћине.

Кључне речи: кратке прозне форме; народне пословице; народне загонетке; култура миграната; култура домаћина; културно наслеђе; верско наслеђе.

Кратке прозне форме, нарочито народне пословице и загонетке, баштиници су културног и верског наслеђа једног народа. Оне носе собом веровања, обичаје, обреде, уврежена схватања, заблуде, предрасуде, уобичајене ставове о друштвеним појавама, међуљудским односима, 
природним релацијама и њиховом доживљавању. Они каткад о једном народу откривају више од обимних етнографских и историјских студија, а истовремено кроз игру и досетку могу да буду облик едукације, културног приближавања и елементарног овладавања лингвистичким вештинама, значајним како за мигранте, тако и за домаћине.

У овом нестабилном добу, у коме су извештаји о миграцијама честа појава у свим медијима, у коме се сви сусрећемо са мигрантима у градовима у којима живимо и за које никада нисмо претпостављали да могу бити суочавани са оваквим изазовима, у коме су људска страдања ретко када праћена разумевањем, а ако јесу, онда је то разумевање углавном материјална и физичка потпора за преживљавање, заборавља се у тешком нестабилном добу и у ситуацијама на које нисмо спремни, заборавља се на културу и образовање. При томе се стално хвалимо да живимо у добу знања. Као да постоје две паралелне стварности. Једна у којој своју децу учимо да је неопходно да се образују, да штите свој културни и етнички идентитет, друга у којој не препознајемо значај ових вредности за оне који под притиском напуштају своје домове и иду у непознато, неизвесно, не мислећи више да је важно да памте ко су и одакле су и да је важно да знају где су и какви су људи који их примају или осуђују. А њихово сећање јесте њихов идентитет. „Свака теорија, сваки принцип,“ писао је српски филозоф Божидар Кнежевић, „само је један танак конац извучен из сплета општег процеса. Али, то је читав конац. Што је дужи тај конац, тим је и теорија дубља и истинитија.“ Прве спознаје у култури сваког појединца везују се за народне умотворине, најчешће за кратке прозне форме, басне, бајке, пословице, загонетке, питалице. Оне носе народну мудрост о људском карактеру, темпераменту, природи међуљудских односа, такозваним општим истинама и животним изборима, оне су искре народне духовитости и виспрености, чувари локалних обичаја и обреда. Често нисмо свесни да су нам оне поштапалице у озбиљним разговорима, извор потврђивања наших теза, валиднији од научних истина. Дакле, 
немамо разлога да њихову функционалност запостављамо ни када су у питању потребе превазилажења и међусобног упознавања културолошких разлика, а самим тим и успостављања бољег разумевања и поред различитог етничког, верског и културног поднебља.

И Србија је као земља на раскршћу западних и источних путева и ветрова, привремено или трајно удомљавала, а то чини и даље, бројне мигранте. Примајући их, Србија je, као и друге државе, морала да разуме међународне стандарде заштите у области миграција и азила и да их имплементира у национални контекст, кроз национални законодавни и регулаторни оквир. Познавањем и разумевањем феномена миграција и осетљивости мигрантске популације и кроз стицање увида у карактеристике одговора локалних система на прописе у остваривању права миграната дошло се и до формулисања препорука за унапређење одговора на потребе миграната и посебно осетљивих група миграната и за њихову интеграцију у локалне заједнице. Мигранти који пролазе кроз Србију углавном желе да стигну до развијених земаља које имају и ефикаснији систем азила, па ипак се број тражилаца азила повећава из године у годину, а Србија постаје земља жељене крајње дестинације. Стога је систематична и темељна помоћ неопходна, не само на плану материјалног, правног и здравственог обезбеђивања, већ и на плану укључивања у образовни систем и развијања транскултуралности. Инсистирање на транскултуралности појачава сензитивност и миграната и локалног становништва, омогућава виши степен сарадње, па самим тим и бољу ефикасност у успостављању комуникације која поступно води ка задобијању поверења једних у друге. Мишљења смо да би дистрибуција едуктаивних материјала, обима једне до неколико страна, на српском и на језику миграната допринела буђењу њихове радозналости за народ коме су се припојили, као што би едукација локалног становништва о мигрантима, њиховим потребама и култури, ако занемаримо агресивно медијско саопштавање, значајно 
допринела њиховој већој благонаклоности. Тиме би се подржао процес интеркултуралне медијације, чији би резултат свакако било међукултуролошко разумевање.

Интеркултуралност је процес, који се остварује у трајној дијалектици између јединства и различитости, институције и интуиције, општости и посебности, сећања и будућности, веровања и сведочења, одговора смисла и свакодневних захтева, отварања и затварања. Једино озбиљни процес интеркултурализма, који води рачуна о свим деловима пута што га треба прећи, надвладава затварања и отвара простор за тражење онога јединства које не умртвљује различитост. Површни приступ интеркултурализму води губитку идентитета, или апсолутизацији посебнога. Како идентитет није дат једном засвагда, већ се дограђује, мења, стиче, развија у контакту са другима, то је транскултуралност неопходност нашег времена. Показивање и постизање „људског лица“ и ,људске димензије“ почива на „људском праву“ и ,људском достојанству“, којих има у духовном наслеђу сваког народа више него у његовим законима. То је задатак озбиљног школског система, али је у међувремену и задатак за креативне невладине организације или алтернативне образовне покрете и пројекте. Објављивањем публикација у којима су народна домишљатост и традиција везани за ликовни израз,чиме се подржава интермедијалност; за адекватну лингвистичку базу, у виду речника и граматичких објашњења; за графичку и језичку луцидност, у облику мозгалица, лавирината, укрштеница; за отварање међусобних поређења културе избеглица и културе прималаца, кроз навођење прича, изрека и доскочица са истим или сродним значењем - подстичу, с једне стране, информисаност и заинтересованост, а са друге, самопоштовање миграната, јер се не занемарује њихова потреба за образовним и културним садржајима. Тако се једној маргинализованој друштвеној групи поручује да желимо да упозна културни контекст земље у којој се тренутно задржава, чиме се, на један академски начин, у потпуно неакадемским и пони- 
жавајућим животним условима, дошљацима шаље порука да нам је стало да се упознамо. Довољно за културни оптимизам.

Пословице и загонетке јесу најкраћа, али и духом најбогатија књижевна форма. Етиопљани сматрају да су «речи без пословица као јело без соли», а Узбекистанци да су «речи дедова извор мудрости». Оне обухватају све важне области живота и представљају значајно сведочанство духовног трајања сваког, и нашег народа. Пословице су народна филозофија и свезнање. Сажете и једноставне по облику, згуснуле су мисли и емоције у јаке слике и избрусиле језички израз у необичне драгуље.

Нарочито су важна међукултурална поређења. Сликовите су и у арапску културу дубоко утемељене пословице:

„Ко посеје добро, жњеће хвалу.“

„Новац је добар као слуга, али је лош као господар.“

„Пашче маше репом, а лицемер језиком.“

„Боље је сироту за жену узети, него се са богатом чупати.“

„Ако хоћеш да спознаш женску бит, гледај у жену затворених очију.“ је враг.“

„Ко погреши, тај је човек; а ко на грешци устраје, тај

Свакој од њих можемо да нађемо паралелу и у сваком народу. Библиотеке, као институције културе и образовања усмерене свима без обзира на расу, пол, економски положај, узраст, најбоља су стецишта културне знатижеље, па се зато очекује и њихово веће културно ангажовање. Broekhof (2011) обавља истраживање и установљује да дете које чита 15 минута дневно, прочита милион речи током године и обогати свој речник са 1000 речи. Sullivan и Brown (2013), који су истраживали национални узорак британских 6000 држављана установили да се речник са потпуно истом успешношћу и залагањем развија у узрасту од десет и шеснаест година. И други истраживачи (Krashen, 2013) су потом установили да је читање из забаве и ради опуштања давало боље резултате за развијање 
речника читаоца. Отуда су форме пословице и загонетке, које додатно развијају креативност и маштовитост (Gille et al., 2010; OECD, 2011a) изузетно пожељне за овај облик спознавања навика и карактера околине. Ка другим формама читалац се, уз помоћ библиотекара, посебно креће, али његова упорност и сигурност у процесу читалачке социјализације зависи у највећој мери од његовог задржавања у земљи у коју је пристигао. Од тога, наравно, зависи и начин на који ће се образовни систем једне земље односити према избеглицама. Избеглицама из своје земље, али не избеглицама из своје културе, коју воле, поштују, носе са собом, а за коју им земља домаћин пружа могућност да јој је представе и да се са локалном упознају, како би могли да се навикну и прихвате ново окружење. И вратимо се још једном српском филозофу с почетка 20. века: „Тражење положаја у друштву јесте тетовирање хуманитета.“

\section{Литература:}

Кнежевић, Божидар (2002). Мисли. Прир. Александра Вранеш. Уб : Градска бибиблиотека „Божидар Кнежевић“.

Gil-Gonzalez, D., M.T. Ruiz-Cantero and C. Alvarez-Dardet (2009), "How political epidemiology research can address why the millennium development goals have not been achieved: Developing a research agenda", Journal of Epidemiology and Community Health, Vol. 63, Issue 4, April 2009, pp. 278-280.

Broekhof, K. (2011). Meer lezen, beter in taal. Effecten van lezen op taalontwikkeling [More reading, better in language. Effects of reading on language development]. Retrieved from http://www. siob.nl/ media/documents/Meer-lezen-beter-in-taal-3e-druk.pdf

Sullivan, A. and Brown, M. (2013) Social inequalities in cognitive scores at age 16: The role of reading. CLS Working Paper 2013/10. London: Centre for Longitudinal Studies. This paper has now been published as a journal article in the British Educational Review Journal.

Language Acquisition without Speaking and without Study. (Journal of Research of Bilingual Educaiton Research and Instruction 16(1): 215221. 2014.) CHristy Lao and Stephen Krashen Posted: 2017-02-23 
Prof. Aleksandra Vraneš, $\mathrm{PhD}$

Prof. Ljiljana Marković, PhD

University of Belgrade

Faculty of Philology

\author{
SHORT FOLK PROSE FORMS \\ (PROVERBS AND RIDDLES) \\ AS CARRIERS OF CULTURAL AND ETHNIC \\ HERITAGE OF MIGRANTS AND DOMESTIC
}

\title{
Summary
}

Short prose forms, especially folk proverbs and riddles, are carriers of the cultural and religious heritage of a nation. They carry beliefs, customs, rituals, insights, misconceptions, prejudices, common attitudes about social phenomena, interpersonal relations, natural relations and their perception. They sometimes reveal to a nation more than extensive ethnographic and historical studies, and at the same time through play can be a form of education, cultural approximation and elementary mastering of linguistic skills, important for both, migrants and hosts.

Key words: short prose forms; folk proverbs; folk riddles; culture of migrants; culture of the host; cultural heritage; religious heritage. 